\title{
ON SOME OF THE CONDITIONS OF LOSS BY VOLATILIZATION IN CERTAIN METALLURGICAL OPERATIONS,
}

By Chames P. Williams, Prof. of Chemistry, ete, Delaware College.

It is a well recognized fact, pointer out by an expensive experience, that in all methods of lead smelting and in oxidlizing and chloridizing roastings generally, a very considerable loss of metals results. This loss is brought about either by the formation of more or less volatile compounds, or by the draught of the furnace carry. ing, mechanically suspended, particles of chemically changed ore, with the products of combustion, or, in the case of muffle furnaces, with the atmosphere sweeping over the ore therein treated. The problem of devising an economical and complete method of collecting these metallic vapors or fumes is one of very considerable difficulty, and it may be fairly questioned if it has yet received a sat. isfactory solution. In this country where rich lead ores are abundant, and where all the elements, except labor, entering into the metallurgical treatment of such ores are comparatively cheap; this matter of condensation and collection has not generally forced itself upon the attention of practical metallurgists, but it is nevertheless of considerible significance.

In the treatment of silver-bearing ores by smelting operations, or where a previous chloridizing roasting is necessary, the loss of silver by volatilization must be of significant importance and will yet, if it has not already, give rise to a study of the means adapted to its prevention. Various European experimenters have given different figures for the loss of silver by volatilization in different methods of its extraction, but these figures may safely be averaged as ranging between 0.5 and 4 per cent. of the content of the origi. nal ore. With regard to chloride of silver it is well established that its volatility is greatly increased by the presence of other chlorides. Plattner's experiments on the Augustin method of silver extraction, * show that a mixture of 10 parts of oxide of copper, 3 of chloride of lead and 0.6 of fused and finely divided chloride of silver, lost, on roasting in a current of air, 6.61 per cent. of the original weight by volatilization. The sublimate, on quantitative examination, gave 63.8 per ct. chloride and oxide of lead, (containing 54.8 of metallic lead), 32.8 per cent. of cuprous chlor.

\footnotetext{
* Berg-und Hüttenmänische Zeitung, 1854, p. 325 , et. seq.
} 
ide, (containing 21 of copper,) and $3 \cdot 1$ of argentic chloride, (containing 2.6 of silver). These figures would give 5.09 as the per centage of the loss of the chloride of silver contained in the original mixture, partly due to the volatility of chloride of silver itself, but chiefly brought about, however, by the presence of other chlorides. In the oxidizing roasting of sulphuretted compounds of silver, the loss is also great, through the volatilization of the sulphate, etc., of themselves, or increased by the presence of com. pounds of other metals, or through the mechanical movement of fine particles of the ore by the draught through the furnaces.

In the treatment of galena for the extraction of lead, whether by the process of reaction or by other means, a large amount of the metal is lost, chiefly in, the forms of sulphate or of oxide. This loss, though admittedly large, is not fully appreciated, and is, without doubt, due, not merely to the volatility of the oxide of lead, (this being partially changed into sulphate:) but also to the facts that sulphate of lead is volatile, and that sulphide of lead is readily and rapidly volatilized at elevated temperatures and is sub. sequently converted into sulphate either through the action of the oxygen of the air or through that of sulphuric acid. This latter production of sulphate is well established by the researches of Plattner, * and his observation of pseudomorphous crystals of plumbic sulphate after sulphide of lead, which had formed after the condensation of the latter erystals from a vaporous condition. The writer of this communication has invariably observed during repeated exhaustive analyses of the so-called Bartlett White Lead, and of oxide of zinc produced at the Keystone Zinc Works, the presence of sulphide of lead. Both of these substances are essentially mixtures of oxide of zinc and plumbic sulphate obtained by the treatment of mixed galena and blende by the well-known pro. cess for the manufacture of zinc white directly from the ores. On treatment with hyposulphite of soda the sulphate of lead is readily dissolved, whilst a subsequent addition of dilute acetic acid will dissolve the remaining ingredients, leaving a small amount of dark metallic particles, which, on chemical and microscopic examination, are found to be minute crystals of sulphide of lead.

Mr. Geo. T. Lewis, a well-known manufacturer of this eity, has repeatediy completely volatilized several hundred pounds of the purest galena obtained in the Wisconsin lead region. The pro-

* Procedes Metallurgiques de Grillage, p. 207, et, seq. 
ducts of these treatments, (which were chiefly conducted in the Wetherill furnace for the manufacture of zinc white,) were collectel by the "bag process," and have been analyzed by the author. They are mixtures of sulphate of lead, (commonly about sixty per cent.,) with some oxide of lead and zinc, and carbonate and sulphite of lead, and invariably contain small and variable amounts of sulphide of lead.* From these experiments the high degree of volatility of this last named compound must be admitted, unless it be claimed that it is first converted into sulphate, and that this salt is even more volatile than the sulphide. The author has made efforts to establish the degree of volatility of the sulphide of lead by strongly heating the artificially prepared salt in currents of nitrogen and hydrosulphuric acid, but has found so many difficulties in the preparation of a perfectly dry and unaltered compound that he cannot, as yet, regard his results as removed beyond sources of fallacy.

Plumbic sulphate is also to a slight degree volatile. Some of the perfectly dry and pure artificially prepared salt was strongly heated for one hour in a porcelain tube through which a current of dry air, freed from carbonic acid, was drawn. Thus treated, 1.4082 grammes of the sulphate lost in weight 0019 grammes, equivalent to 0.134 per cent. A second experiment with 4.2761 grammes, but heated for upwards of two hours, showed a loss of 8.5 millegrammes, or a little less than 0.2 per cent. Other trials showed variable losses, but in no instance was the percentage amount greater than that obtained in the second experiment. Examined with a glass, indications of fusion of the sulphate were noticed. That this method of producing sulphate of lead in lead smoke or fumes is of much moment compared with that of the volatilization and subsequent oxidation of the sulphide, can hardly be claimed, though it doubtless is one of the many causes of the loss of lead in metallurgical operations.

Another cause of loss is the mechanical one brought about by the currents of air or of the products of combustion sweeping through the furnaces. In furnaces of that description where the fuel is intermingled with the ore under treatment, or where the gases, vapors, etc., from the fuel in the fire box pass over and in contact with the charge, this mechanical loss is doubtless increased

* The method of analysis followed in these investigations was essentially that described by the author in this Journa! for March, 1869. 
by the presence of fuliginous particles of finely divided carbon which enclose, and, as it were, buoy up the denser particles of metallic compounds. Where the metallurgist has to deal with lead ores which contain zine compounds--by no means an unusual condition of affairs -it will be admitted that the formation of zinc vapors and their subsequent conversion into the specifically light oxide of zinc, will add greatly to the loss of lead as sulphide or as oxide by assisting mechanically in carrying these compounds from the furnace in a manner similar to that in which the sooty particles of carbon may act. The volatility of silver as oxide or as sul. phate may be fairly assumed as increased in this same manner. The experiments of Malaguti and Durocher, ${ }^{*}$ made with argentiferous zinc blende, indicate that the loss of silver in the presence of zinc compounds may be very considerable, reaching as much even as 70 per cent. of the original content of the ore, but ranging usually according to the richness of the ore in silver and in zinc, and according to the management of the furnaces, between 15 and 66 per cent. $\dagger$ A small proportion of this loss is unquestionably due to the volatility of the sulphate of silver, but, as in the case of ores not carrying zine, and not highly silicious, the loss is less tban 10 per cent, it must be admitted that zine compounds dispose silver to volatilize.

The ores mined in the Silurian lime-stones of Sinking Talley are chiefly intimate mixtures of zine blende and galena, (the latter forming usually about 20 per cent. of the mixture,) and contain on the average, by the assays of the author, about five ounces of silver to the ton of $2000 \mathrm{lbs}$, though Ashmead finds by his assays 8.5 and 9 ounces. These ores are treated, at the Keystone zinc works, for the manufacture of zinc white by the ordinary process, and in the residues on the perforated grate bars of the furnace, the writer has never been able to find weighable quantities of silver, though operating repeatedly on amounts of $58 \frac{1}{3}$ grammes. By dissolving a weighed amount of the so-called "oxide" made from this ore and collected in the "bags," in nitric acid, evaporating to dryness, adding bydrochloric acid, extracting with water and assaying the residue in the asual manner, 0.014 per cent. of silver may be found,

* Annales des Mines, XVII., 1850.

iे Plattner, loc. cit, p. 118.

; Kerl's Handluele der Itïttenkïnde, I., 2d Edition, p. 89.

3. American Chemist, Vol. I., No. 4, p. 134. 
corresponding to 4.2 ounces to the ton of "oxide." The "Bartlett White Lead," prepared in a similar manner from mixed blende and galena, mined in Davidson county, North Carolina, yields a somewhat smaller percentage of silver, $(0.0087$ per cent., $)$ though the original ore is more highly argentiferous than that utilized in Pennsylvania. This discrepancy may be accounted for, however, by the fact that the Xorth Carolina ore is roasted (with the addition of salt?) at the mine before shipment to New Jersey for its conversion into the basis of a pigment.

The following analyses will exhibit the composition of lead fumes by various operations:

\begin{tabular}{|c|c|c|c|c|c|c|}
\hline & No. I. & No. II. & No. III. & No.IV. & No. V. & No. VI. \\
\hline $\operatorname{ZnO} \ldots \ldots . . . .$. & 72080 & $73 \cdot 426$ & 49.50 & $13 \cdot 80$ & $25 \cdot 70$ & $9 \cdot 23$ \\
\hline Pbo................ & .274 & $\ldots \ldots$ & $27 \cdot 90$ & $10 \cdot 20$ & 48 & $13 \cdot 21$ \\
\hline $\mathrm{bO}_{3} \ldots \ldots \ldots \ldots$ & trace. & ....... & $\mathrm{AgO}_{3} 2 \cdot 10$ & & $3 \cdot 90$ & \\
\hline $\mathrm{Fe}_{2} \mathrm{U}_{3} \ldots \ldots \ldots \ldots$ & "6 & & & $\because 40$ & & trace. \\
\hline I'bo & $23 \cdot 958$ & $2 \cdot 084$ & $13 \cdot 00$ & $66 \cdot 60$ & $14 \cdot 40$ & $74 \cdot 05$ \\
\hline $\mathrm{Zn} \mathrm{OSO}_{3}{ }^{\prime \prime} \ldots \ldots$ & .810 & .674 & ...... & PbS. $1 \cdot 40$ & $\ldots \ldots$ & trace. \\
\hline $\mathrm{Zn} \mathrm{Ol} . . . . . . . .$. & $\cdot 839$ & $\cdots \cdots$ & ....... & $\cdots \cdots$ & $\cdots \cdot$ & $\cdots$ \\
\hline $\mathrm{Fe}_{2} \mathrm{Cl}_{3}, \ldots \ldots$. & .071 & $\ldots \ldots$ & $\cdots \cdots$ & .. & .. &.. \\
\hline $\mathrm{Sb} \quad \mathrm{Cl}_{3}, \ldots \ldots \ldots$ & trace. & ...... & $\cdots \cdots$ & .... & …" & $\cdots \cdots$ \\
\hline 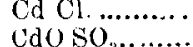 & $\cdot-256$ & $.18 \pi$ & $\cdots \cdot$ & $\cdots$ & (n.... & $\cdots$ \\
\hline CaO $\mathrm{CO}_{2}, \ldots \ldots \ldots$ & ........ and & loss 729 & $\mathrm{CO}_{2}-7 \cdot 00$ & $\ldots .$. & $\dddot{4.50}$ & $3 \cdot 27$ \\
\hline Clay,................ & ...... & $\ldots \ldots$ & $\ldots \ldots$ & $5 \cdot 60$ & $\cdots \cdots$ & $\mathrm{SO}_{2} \cdot 84$ \\
\hline $\begin{array}{l}\text { Per cent. } \mathrm{Pb} \\
\text { in above } \ldots . .\end{array}$ & $16 \cdot 624$ & $17 \cdot 132$ & $34 \cdot 778$ & $56 \cdot 169$ & 54.571 & $62 \cdot 840$ \\
\hline $\operatorname{Ag} \ldots \ldots \ldots \ldots$ & $0.008 \bar{i}$ & 0.014 & & & & .0 \\
\hline
\end{tabular}

Analyses I., II. and VI. are by the author; III., IV. and V. are from Watt's Dictionary of Chemistry, Art. Lead. No. I. is the so-called Bartlett W hite Lead, (this Journal, March, 1869); II. is the zine white from the ores of Sinking Valley, Pennsylvania; III., fumes from blast furnaces at Freiberg; IV., fumes from reverberatory furnace at Alston Moor; V., from refinery at Freiberg; VI., from Wisconsin ores treated at Birmingham, Pennsylvania, in the Wetherill furnace for the manufacture of zinc white; Nos. I. and II were also obtained by treatment in the same furnace. The three analysed by the author all contained sulphide of lead, but the amounts were small and were not estimated.

Estimates based upon the treatment of a large amount of ores have given the following figures, making evident the loss in the 
treatment of lead ores by conversion into merchantable lead, though unfortunately no descriptions of the characters of the ores are furnished: A blast hearth furnace treating 267,008 pounds, yielding by assay 75.75 per cent., or 202,258 pounds, gave 178,895 pounds or 67.00 per cent, exhibiting, therefore, a loss of 23,363 pounds. The refining process gave a further loss of 13.40 per cent, whilst the reduction of the dross from the refinery added a still further loss of 3.60 per cent., giving an aggregate of more than $28 \frac{1}{2}$ per cent. of the original content of lead.*

If considerations of the health and property of a neighborhood are only of subordinate importance, such figures must make evident the necessity of connecting, with lead establishments, suitable apparatus for the condensation and saving of this fume. The process of straining the furnes through muslin or fine canvass, which gives such successful results in the collection of zinc fume or oxide as exemplified by the well known "bag process," has not received from metallurgists the attention its simplicity and completeness merit. From experiments made on a large scale on galena ores, both nearly pure and containing a large amount of blende, the writer is satisfied that its application to the condensation of lead and other metallic fumes would leave little to be desired. It seems strange that it has not been applied to purposes other than the more saving of oxide of zinc, especially when the necessity of a thorough collection of metallic fume is considered. Its satisfactory use in the treatment of sulphuretted ores, it is true, would be somewhat less. ened by the fact that the fabric of the bags would be rapidly destroyed by sulphuric acid, etc; but even this difficulty might be obviated by washing the mixed gases and metallic vapors by conducting them into a brick chamber through which water in the form of rain is falling. 'The water from this chamber might be run off' through caustic lime to remove soluble metallic salts. The ordinary blower working in the flues between the zinc furnaces and the bags would prevent any injury to the draught of the furnace.

A discussion of the various mechanical devices and combinations already in use in England and elsewhere for preventing or reducing the loss by volatilization at lead furnaces is not deemed necessary in this connection. The results of Von Patera's experimentst made on a small scale, and having in view the saving of argentiferous fume through chemical reagents and reactions, may yet be found to contain the germs of important technical applications. Especially may this be true of those obtained by the use of sulphydric acid whereby waste sulphurous acid may be converted into sulphur, and a complete saving of volatilized silver and lead compounds be effected.

* These figures a re condenscd from the elaborate tables in Watt's Dictionary of Chemistry.

+ Zeitschriftfür Berg-und Hütenuesen, 1851, 23:

Newark, DeL, December 2?, $18 ; 0$. 